\title{
Recension av Rune Bokholm, Kungen av Skåne. En bok om statsmannen Arvid Posse (Historiska Media 1998)
}

\section{Av Börje Björkman}

\section{Länk till presentation av Börje Björkman}

Till den växande raden av professionella historiker som intresserat sig för de enskilda individerna i historien och som även skrivit en biografi hör lundahistorikern Rune Bokholm. Med Kungen av Skåne. En bok om statsmannen Arvid Posse har han presenterat ett gediget arbete om greven, storjordägaren, bankmannen, järnvägsbyggaren, riksdagsmannen och sedermera statsministern Arvid Posse som föddes år 1820 och dog dryga åttio år senare, våren 1901. Epiteten kring denne man har varit många och därtill av starkt skiftande slag; såväl hyllande som kritiska, såväl av samtiden som i eftervärlden. Inte minst de skiftande omdömena om Posses person är intressanta, eftersom det delvis var här som författarens intresse för honom vaknade, eller närmare bestämt med några kraftigt svartmålande nekrologer skrivna strax efter hans död. Den fråga som Rune Bokholm ställde sig var hur dessa negativa bilder kunde gå ihop med alla de offentliga och framstående uppdrag som Arvid Posse haft och med de i flera fall positiva omdömen som också fälldes om honom och hans livsgärning. Nekrologer, även över politiska motståndare, brukar ju i allmänhet vara övervägande positiva nästan oavsett vilken inställning man haft till honom eller henne under livstiden.

Utan att avslöja alltför mycket av innehållet i denna digra volym kan ändå sägas att den tidsperiod som står i centrum här sträcker sig från 1850- till 1890-talet även om Posse i och för sig spelade en betydande roll i såväl svenskt som skånskt närings- och kulturliv under längre tid. Tillnamnet "Kungen av Skåne" fick Posse redan av samtiden, ett epitet som rymmer både positiva och negativa nyanser ty Arvid Posse var på flera sätt en kontroversiell person, med ibland egensinniga och oftast mycket bestämda åsikter. Mest känd utanför Skåne har nog Arvid Posse blivit i rollen som politiker. Arvid Posse var en av de drivande männen bakom bildandet av Lantmannapartiet - Sveriges första, i modern mening politiska parti som grundades år 1867 - satt trettiofem år i riksdagen och var dessutom statsminister under några i och för sig korta men för landet viktiga år på 1880talet. En tes som Bokholm driver är att förklaringarna till en hel del av Posses verksamhet som politiker kan sökas i de erfarenheter han skaffade sig på andra områden, inom juridiken såsom den domstolsjurist han var och i föreningslivet som den föreningsmänniska han också var, och vidare som den bankman och den föregångsman han var för byggandet av järnvägar. Och naturligtvis även omvänt, att hans politikergärning färgade av sig på hans övriga agerande.

Att skriva biografier som går på bredden såväl som på djupet och som både ger en rättvisande och mångskiftande bild av personen och tiden är svårt. Detta delvis därför att biografier ju kan vara så olika till sin karaktär och sitt syfte. De kan som Rune Bokholm skriver "ligga någonstans mellan en skvallerkrönika och en vetenskapligt accepterad avhandling med fullständig akribi". Själv har Bokholm valt en medelväg mellan de nyssnämnda 'polerna' och medvetet gett avkall på vetenskapligheten i form av tunga litteratur- respektive forskningsgenomgångar samt hoppat över djupare problemgenomgångar till förmån för en mer populär och läsvänlig bok som icke desto mindre innehåller en notapparat och en källförteckning som gör det lätt för den vetgirige läsaren att själv gå vidare.

Personligen tycker jag att Rune Bokholm lyckats i sitt syfte. Kungen av Skåne är 
visserligen ett ganska omfattande verk - enbart själva texten (förutom noter och källförteckningar) stannar på dryga fyrahundra sidor - men trots detta så har man sällan tråkigt i Bokholms/Posses sällskap. Detta är en mycket läsvärd bok som utifrån en persons liv och gärning också ger många inblickar i politiken och i närings- och kulturlivet under förra seklet. Den gavs visserligen ut redan förra året men kan icke desto mindre tryggt rekommenderas till alla som redan nu börjar ställa in sig på ett somrigt hängmatteläsande år 1999.

\section{(C) Börje Björkman}

